\title{
Morphoanatomy of fruit, seed and seedling of Ormosia paraensis Ducke ${ }^{1}$
}

\author{
Breno Marques da Silva e Silva ${ }^{2 *}$, Camila de Oliveira e Silva ${ }^{2}$, \\ Fabíola Vitti Môro ${ }^{3}$, Roberval Daiton Vieira ${ }^{4}$
}

\begin{abstract}
Ormosia paraensis Ducke, known as "tento", has seeds that are used to make handcrafts and wood that is worked on by furniture makers. For forest identification and seeds technology, the information about the morphoanatomy of their fruits, seeds and seedlings is scarce. Therefore, the purpose of this study was to morphoanatomically describe the fruit, seeds and the post-seminal development of "tento". For the morphoanatomical description, the evaluations were examined by optical and electron microscopy scanning. The fruit is a nutant legume, brown to black, dehiscent and with one or two seeds of lateral placentation, being the epicarp slim, the mesocarp woody and the endocarp spongy, measuring about $4.4 \mathrm{~cm}, 3.9$ $\mathrm{cm}$ and $2.0 \mathrm{~cm}$ in length, width and thickness, respectively. The seeds are bitegmic, exalbuminous and rounded with average dimensions: length of $12.36 \mathrm{~mm}$, width of $9.68 \mathrm{~mm}$ and thickness of $8.03 \mathrm{~mm}$. The "tento" seedlings have simple and alternate leaves, with tap roots and cylindrical stem, being its germination hypogeal cryptocotyledonary.
\end{abstract}

Index terms: morphology, post-seminal development, germination, Fabaceae.

\section{Morfoanatomia do fruto, da semente e da plântula de Ormosia paraensis Ducke}

\begin{abstract}
RESUMO - Ormosia paraensis Ducke, conhecida popularmente por tento, possui sementes ornamentais amplamente usadas na confecção de biojóias, assim como, sua madeira é usada na indústria moveleira. Para a identificação florestal e tecnologia de sementes, as informações sobre a morfoanatomia de seus frutos, sementes e plântulas são escassas. Desta forma, o objetivo no presente trabalho foi descrever morfoanatomicamente o fruto, a semente e a plântula de tento. Para a descrição morfoanatômica de tento, os frutos, as sementes e as plântulas foram avaliados por meio de microscopia óptica e eletrônica de varredura. O fruto de tento é um legume nucóide, pseudo-septado, castanho a preto, deiscente, portando uma ou duas sementes, de placentação lateral, sendo o epicarpo delgado, mesocarpo lenhoso e endocarpo esponjoso, medindo cerca de 4,4;3,9 e 2,0 cm de comprimento, largura e espessura, respectivamente. As sementes são bitegumentadas, exalbuminosas, arredondadas, com dimensões médias: comprimento de $12,36 \mathrm{~mm}$, largura de $9,68 \mathrm{~mm}$ e espessura de $8,03 \mathrm{~mm}$. As plântulas de tento apresentam folhas simples e alternas, com raiz pivotante e caule cilíndrico, sendo a germinação do tipo hipógea criptocotiledonar.
\end{abstract}

Termos para indexação: morfologia, desenvolvimento pós-seminal, germinação, Fabaceae.

\section{Introduction}

The Fabaceae family has a worldwide distribution, including about 650 genera and 18,000 species, divided into four subfamilies: Caesalpinioideae, Faboideae (Papilionoideae), Mimosoideae and Cercideae with approximately 200 genera and about 1,500 species in Brazil (Souza and Lorenzi, 2012).

In the Amazon rain forest, the Fabaceae's economic importance is marked by many timber, herbal (antifungal and anti-inflammatory), dyes, oil, fruit, insecticides, repellents, and ornamental species and are used to make handicrafts,

${ }^{1}$ Submitted on 6/29/2015. Accepted for publication on 9/29/2015.

${ }^{2}$ Universidade do Estado do Amapá, 68906-970 - Macapá, AP, Brasil.

${ }^{3}$ Departamento de Biologia Aplicada a Agropecuária, UNESP, 14884-900 Jaboticabal, SP, Brasil. among others (Ferreira et al., 2005; Chevreuil et al., 2011).

Ormosia paraensis Ducke, popularly known in Brazilian Portuguese as tento, tenteiro or olho-de-cabra, is a tree species widely distributed in the dense ombrophilous forests and ancient capoeira shrubs in the Amazon rain forest. By virtue of the straight shaft without branches and dense wood, tento is of interest to the wood industry. Moreover, the potential for nodulation and nitrogen fixation, characteristic of legumes, is more attractive for use in reforestation, afforestation and replanting of degraded areas with tenteiro (Carneiro et al., 1998; Lorenzi, 2002).

The characterization of Fabaceae's morphological

${ }^{4}$ Departamento de Produção Vegetal, UNESP, 14884-900 - Jaboticabal, SP, Brasil.

*Corresponding author <silvabms@hotmail.com.br> 
and anatomical structures of fruits, seeds and seedlings is the goal of several studies aiming to solve taxonomic problems, subsidize species identification, and understand ecological and physiological strategies, among others (Melo-Pinna et al., 1999; Barroso et al., 2007; Silva and Môro, 2008).

Seeds internal and external morphology, combined with seedlings observations, allow the identification of structures, offering, in the laboratory, subsidies for the correct interpretation of germination, identification and certification tests of physiological quality. Therefore, it can assist seed technology studies, and, in the nursery, contribute to the recognition of the species and methods suitability for producing seedlings for various purposes (Andrade et al., 2003; Rego et al., 2007). However, for most Amazonian legume species, basic information about the fruits, seeds and seedlings morphology and anatomy are sparse, and for tento, fruit and seed morphology is partially dealt with by Ducke (1925). This way, to aid in the identification in the field, for the benefit of ecological information and the seeds physiology interpretation, the aim of this study was to describe morphologically and anatomically the fruit, seed and post-seminal development of Ormosia paraensis Ducke.

\section{Material and Methods}

The fruits were harvested from ten tento matrices trees (Ormosia paraensis Ducke) located at Parque Natural Municipal "Arivaldo Gomes Barreto" (0002'21"S and $\left.51^{\circ} 05^{\prime} 35^{\prime} \mathrm{W}\right)$, in the Brazilian city of Macapá, AP. Then the fruits were sent for morphological and anatomical analysis at Plant Morphology Laboratory at Department of Biology Applied to Agriculture (DBAA) and at Electron Microscopy Laboratory at Jaboticabal UNESP, Campus Jaboticabal, Jaboticabal, SP, Brazil.

For biometry evaluation, measurements were performed at random for length, width and thickness on 100 fruits and 200 seeds, with the aid of a caliper and a millimeter ruler. Thereafter the fruits and seeds dry matter was determined by drying four replicates of 10 fruits and 10 seeds in a greenhouse at $70{ }^{\circ} \mathrm{C}$ during 72 hours (Benincasa, 2003).

The post-seminal development phases were characterized by sowing 100 seeds without chiseling with no. 8 wood sandpaper, germinated in trays $(35 \mathrm{~cm} \times 20 \mathrm{~cm} \times 12 \mathrm{~cm})$ in washed and sterilized sand, moistened with Maxin XL 0.1\% aqueous solution, maintained in a germination chamber at $30{ }^{\circ} \mathrm{C}$ and with a photoperiod of 8 hours. Every day seedlings descriptions were performed in sequential stages of development, demonstrating the development of the primary root, the emergence of secondary roots, the growth beginning of the first leaf and the conspicuous apical bud, and the expansion of the first eophylls.

The seeds were fixed in FAA (formalin-aceto-alcohol) and then preserved in ethanol 70\% (Johansen, 1940). For the cuts, the seed integument softening was carried out in glycerin 50\% at $100{ }^{\circ} \mathrm{C}$ and then the seeds were soaked for about four hours.

The transverse and longitudinal sections were done by freehand and in a rotary microtome. In this case, the material was previously dehydrated and embedded in paraffin as described by Johansen (1940) and Sass (1958). Subsequently, double staining of the tento seeds sections was done in astra blue and basic fuchsin, according to Kraus et al. (1998).

For the permeability assay, tento seeds chiseled with sandpaper and non-chiseled were dipped in a methylene blue $1 \%$ aqueous solution for $0,1,3,6,12,24,48$ and 72 hours. Subsequently, these seeds were longitudinally sectioned and examined with a stereoscopic microscope to determine the limit penetration of the dye which has molecular weight close to that of water (Melo-Pinna et al., 1999).

Histochemical tests were conducted for starch and cellulose, evidenced with acid phloroglucinol; lipid substances with Sudan IV; mucilage and pectic substances with methylene blue (Johansen, 1940; Sass, 1958).

To observe the tento seedlings leaves surfaces and seeds, they were dried for observation under a scanning electron microscope (SEM), following the methodology described by Santos (1996). The fruits, seeds and post-seminal development phases illustrations were done using a stereo microscope with a camera lucida coupled.

The morphological and anatomical descriptions of fruits, seeds and seedlings were performed following the criteria and terminologies adopted by Esau (1993), Pezzato-da-Glória and Carmello-Guerreiro (2006), Barroso et al. (2004; 2007) and Damião-Filho and Môro (2005).

\section{Results and Discussion}

Tento's (Ormosia paraensis Ducke) fruits are nucoid vegetables, pseudo-septate, brown to black, dehiscent, carrying one or two seeds, of side placentation, and the epicarp is thin, the mesocarp is woody and the endocarp is spongy, measuring about $4.4 \mathrm{~cm}, 3.9 \mathrm{~cm}$ and $2.0 \mathrm{~cm}$ in length, width and thickness, respectively (Figures 1A-B). Likewise, Barroso et al. (2004; 2007) have described the Ormosia Jacks. fruits as vegetable nucoids.

Tento's vegetable nucoids are circular with conspicuous sutures, a slightly peaked end and dorsoventrally prominent due to the central presence of seeds, but they are laterally linked to the fruit through the funiculus, and parietal or side placentation (Figures 1A-B). In fruits with more than one seed, the fruit is constricted between the seeds, but they are false septa, 
as observed in different legumes (Barroso et al., 2007; Silva and Môro, 2008). According to Ducke (1925), tento's vegetables have one to three bicolor seeds.

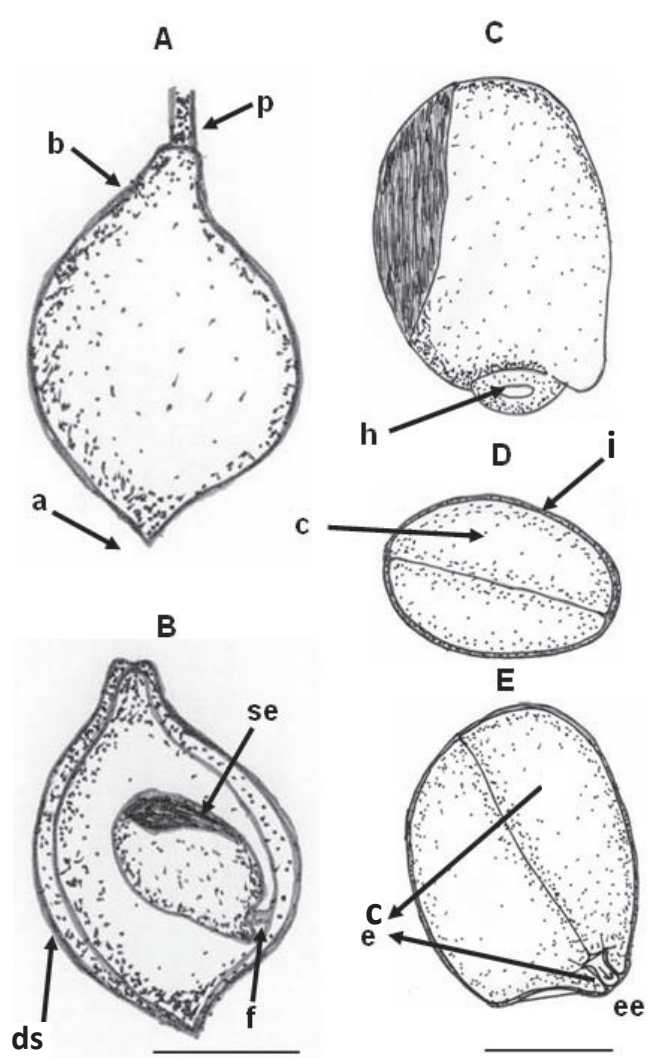

Figure 1. A. Fruit external view. B. Fruit internal view. (Scale: $1 \mathrm{~cm}$ ). C. Seed external view. D. Seed cross cut. E. Seed longitudinal cut (Scale: $0.5 \mathrm{~cm}$ ) of tento (Ormosia paraensis Ducke). Caption: a apex, $\mathrm{b}$ - base, $\mathrm{p}$ - peduncle, ds - dorsal suture, se - seed and $\mathrm{f}-$ funiculus, $\mathrm{i}$ - integument, $\mathrm{c}-$ cotyledon, $\mathrm{h}$ - hilum, ea - embryonic axis and e - embryo. Bar $=0.5 \mathrm{~cm}$.

Tento's seeds are stenospermic, bitegmic, exalbuminous, and rounded (Figures 1C-D-E; Figures 2A-B; Figures 3C-D), with average dimensions: length $12.36 \mathrm{~mm}$, width $9.68 \mathrm{~mm}$, thickness $8.03 \mathrm{~mm}$, average volume $0.463 \mathrm{~mL} . \mathrm{seed}^{-1}$, dry matter of 0.45 g.seed ${ }^{-1}$ and density 0.98 g.mL m. $^{-1}$. Ducke (1925) has similarly noted that tento's seeds have measure 12-13 $\mathrm{mm}$. The integument is formed by a red and black outer layer, glabrous and thin, with a heterochrome (white), elliptical and small hilum relative to the seed, with a side bulge indicating the presence of the embryonic axis (Figures 1C-E; Figure $3 \mathrm{C})$. The tegmen is white and purple and firmly adhered to the embryo. The two cotyledons are free, pale yellow, starchy, massive and plane-convex. The embryo is invaginated (papilionaceous) with a differentiated and small embryonic axis in relation to the seeds (Figures 1D-E; Figure 3C).

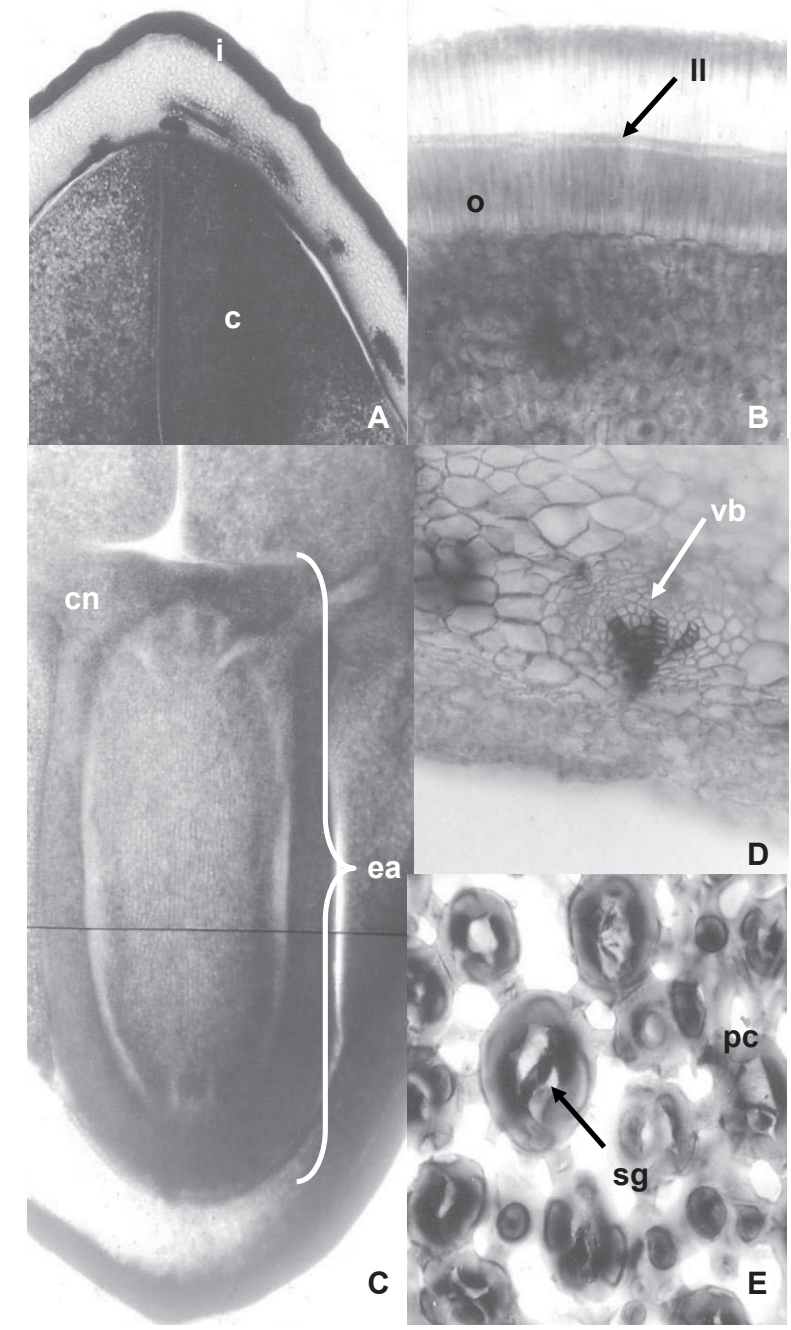

Figure 2. Tento seeds cut (Ormosia paraensis Ducke). A. Integument and cotyledon $(12.5 \mathrm{x})$. B. Integument (lucid line, osteosclereids and palisade layer) (50x) (Transversal). C. Embryonic axis (12.5x) (Longitudinal). D. Vascular bundle (cotyledon) (50x). E. Parenchyma cells (cotyledon) (100x) (Transversal). Caption: i-integument, c-cotyledon, ea - embryonic axis, cn - cotyledon node, II - lucid line, o - osteosclereids, sg - starch grains, pc parenchyma cells, vb - vascular bundle.

The tento's seeds integument has four distinct layers: cuticle (coating with hydrophobic substances), skin (with a compact palisade layer, consisting in radially elongated macrosclereids, unevenly thickened cell walls), hypodermis (hourglass cells, or pillar cells or osteoesclereids) and parenchyma cells (Figures 2A-B/E; Figures 3A-D). 


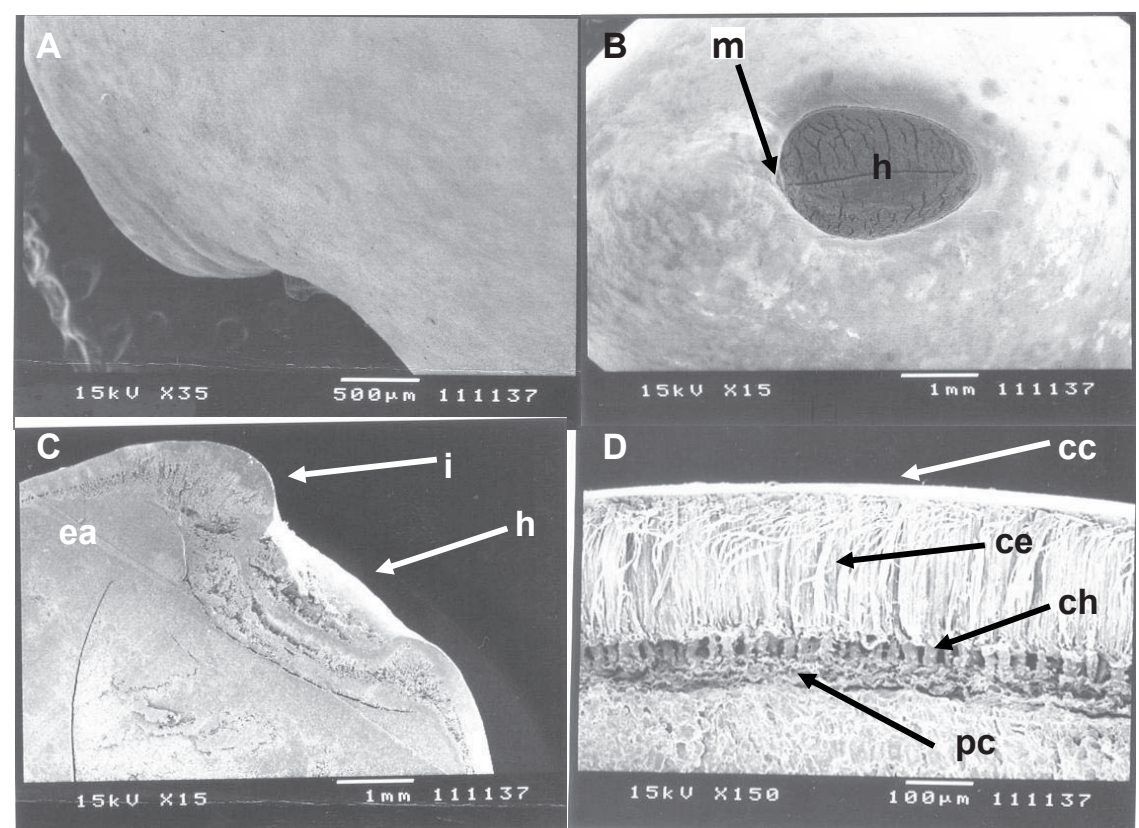

Figure 3. Tento seeds scanning electron micrograph (Ormosia paraensis Ducke - Fabaceae). A. Integument (outer surface view). B. Hilum and micropyle (outer surface view). C. Hilum, micropyle and embryonic axis (longitudinal cut). D. Integument (cross-section). Caption: $\mathrm{i}$ - integument, $\mathrm{h}$ - hilum, $\mathrm{m}$ - micropyle, ea - embryonic axis, cc - cuticle, ce - epidermis, ch - hypodermis and pc - parenchyma cells.

According to Carvalho and Nakagawa (2012) and Baskin and Baskin (2014), the chemical composition, arrangement and intercellular substances of the palisade layer influence the absorption of water by the seed. Lewis and Yamamoto (1990) have reported that lignin is a natural polymer present in the seeds outer layer.

The sclerenchyma cells, called macrosclereids, form the palisade layer of the tento's seeds integument, which continuously appears throughout the outer layer, except for the hilum area, where two palisade layers can be observed (Figure $2 \mathrm{~B}$ and Figure 3C). In this case, the innermost palisade layer comes from the funiculus, while the outermost layer comes from the external integument of the ovule (Esau, 1993). The presence of discontinuity in the integument (pleurogram) was not observed in tento's seeds (Figure 2A and Figure 3D).

The embryo is formed by two cotyledons consisting mainly in parenchyma cells with starch grains and permeated by characteristic vascular bundles of the eudicotyledons, responsible for the translocation of nutrients for growth of the embryonic axis, and the fully differential embryonic axis, adnate through node that is cotyledonary to the cotyledons (Figures 2 C-D-E). Likewise, Corner (1951), Barroso et al. (2007) and Silva and Môro (2008) describe embryos of various legumes seeds.

The hypodermis consists in a uniform layer of cells, continuous across the outer layer, except for the hilum area, where it is absent. It is formed by sclerenchyma cells with cell walls of uneven thickness, called osteoesclereids, with the presence of large intercellular spaces (Figures 3C-D), as observed by Corner (1951) in legume seeds.

The lucid line, a refractive line that runs across the macrosclereids through the integument, is located just above the middle portion of these cells (Figure 2B; Figure 3D). According to Melo-Pinna et al. (1999), the lucid line is usually found in legumes seed integument.

The parenchyma occurs below the hypodermic layer of the seed integument, formed by thickened cell walls of (Figures 3 C-D) of cellulosic nature. Such cells are slightly more elongated at the hilum-chalaza direction, have a thin cell wall and absent protoplasm (Esau, 1993), and are placed in numerically variable strata, according to the seed area.

The tento's seeds germination starts from four days after sowing with primary, cylindrical and white to cream root protrusion. At six days after sowing, there is growth and formation of absorbent hair in the primary root (Figures 4A-B). The development of secondary roots is accompanied by meager hypocotyl elongation. Emergence is marked by strong growth of the epicotyl, cylindrical, green and with thin and hyaline trichomes, and consequent output of sand plumule in about 16 days after sowing (Figure 4C). The epicotyl becomes erect, extends, and at 24 days the formation of protophilus, 
simple and opposite, of conduplicate pre-foliation, is observed. Concurrently, the cotyledons remain below the sand and covered by the integument due to unimpressive development and growth of the hypocotyl (Figures 4C-D).
Thus, tento seeds germination was characterized as hypogealcryptocotyledonary. Similarly, seed germination of Ormosia arborea Ducke is classified as crypto-hypogeal-reserve (Rodrigues and Tozzi, 2007).

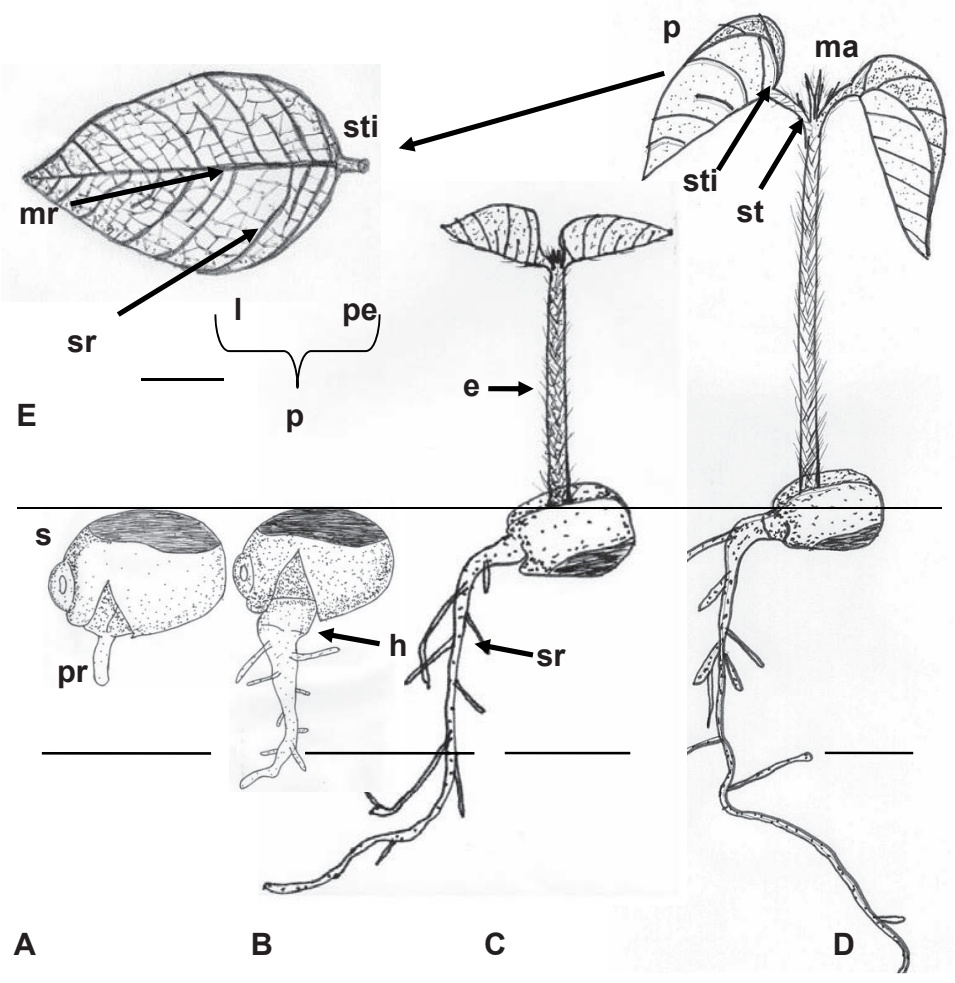

Figure 4. A-D. Post-seminal development. E. Tento seedling protophilus (Ormosia paraensis Ducke - Fabaceae). Caption: $\mathrm{s}$ - substrate, $\mathrm{pr}$ - primary root, $\mathrm{sr}$ - secondary root, $\mathrm{h}$ - hypocotyl, e - epicotyl, st - stipule, sti - stipels, ma - apical meristem, $\mathrm{p}$ - protophilus, $\mathrm{mr}-$ midrib, $\mathrm{sr}-$ secondary rib, $\mathrm{pe}-$ petiole and $1-$ limbo. $\mathrm{Bar}=1 \mathrm{~cm}$.

The tento's protophilus are simple and opposite, with slightly rough leaf blades, and thin and hyaline trichomes, mainly distributed in the midrib, with stipules at the base of the petiole and stipels at the base of the limbo (Figures 4D-E and 5A-B). Likewise, Ormosia arborea Ducke seedlings show stipules and stipels, but with alternate protophilus (Rodrigues and Tozzi, 2007).

The tento's seedling shows the taproot system with axial, cylindrical, and sub-woody primary root, thicker at the base and yellowish, tapered and whitish at the apex, with well developed, branched and irregularly distributed secondary roots (Figure 4D). There is the presence of nodules in the roots, which confirms the statement by Raven et al. (2007) that many members of the Fabaceae family are able to fix nitrogen when associated with bacteria of the genus Rhizobium; for this reason they colonize little fertile soils.

The tento's seedlings leaves are simple, petiolate, with pulvinus, lanceolate, with acuminate apex, smooth margin, reticulate venation, foliaceous limbo, which initially presents clear red color and turns green with development, with the midribs and secondary ribs being evident and the tertiary ones less evident (Figure 4E, Figures 5C-F). The petiole is green, cylindrical, thin, with trichomes, has two stipules and two lanceolate stipels and pulvinus at the base (Figures 4D-E; Figures 5A-B). According to Rodrigues and Machado (2006), the presence of pulvinus is striking in the Fabaceae family.

The protophilus adaxial face is darker than the abaxial and glabrous, and the adaxial midribs are immersed in mesophyll (Figures 5C-E-I), while the abaxial side has trichomes and protruding midribs. The trichomes are concentrated mainly in the midribs and on the edges of the leaf blade (Figures 5D-F-H).

The leaves are hypostomatic and the stomata are paracytic, with epicuticular wax on both surfaces of the blade (Figures 5I-J). Probably the presence of stomata on the leaf abaxial surface is related to the control of water loss, because the incidence of light energy is lower on this surface (Larcher, 2006). 


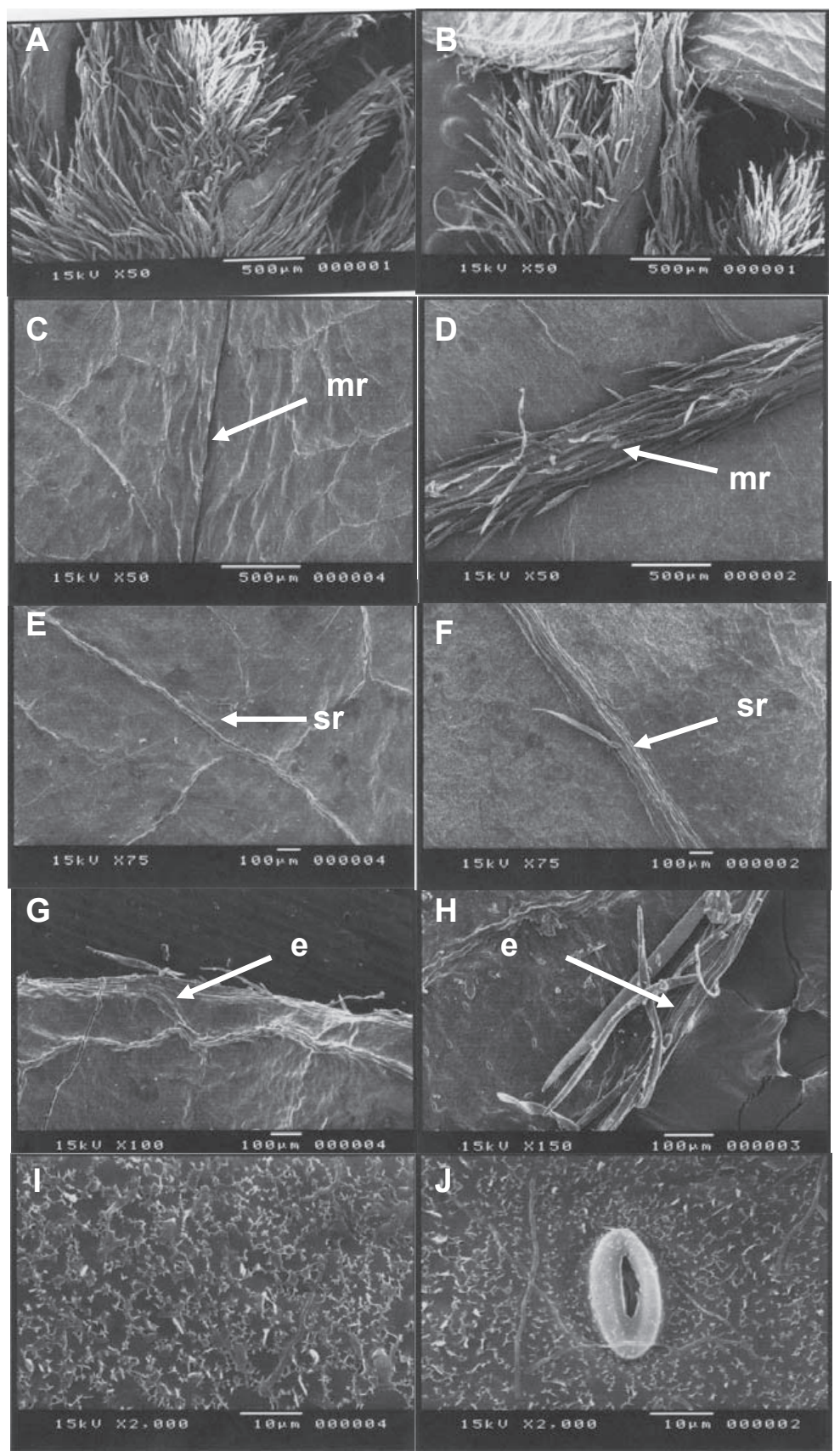

Figure 5. A. Stipules. B. Stipels. C. Adaxial surface - midrib. D. Abaxial surface - midrib. E. Adaxial surface - secondary rib. F. Abaxial surface - secondary rib. G. Adaxial surface - edge. H. Abaxial surface - edge. I. Adaxial surface - epicuticular wax. J. Abaxial surface - epicuticular wax and stomata on the surface of tento seedlings leaf blades (Ormosia paraensis Ducke). Caption: $\mathrm{mr}$ - midrib, $\mathrm{sr}$ - secondary rib, e - edge.

\section{Conclusions}

The characters of fruits, seeds and seedlings are suitable for the test interpretation of germination and vigor, as well as species recognition in the field.

\section{Acknowledgments}

To Jaboticabal UNESP (Universidade Estadual Paulista "Júlio de Mesquita Filho") for the infrastructure and equipment availability. To CAPES for the doctorate scholarship granted to the first author. To CNPq for the Productivity in Research 
scholarship granted to the last two authors.

\section{References}

ANDRADE, A.C.S.; CUNHA, R.; SOUZA, A.F.; REIS, R.B.; ALMEIDA, K.J. Physiological and morphological aspects of seed viability of a neotropical savannah tree, Eugenia dysenterica DC. Seed Science and Technology, v.31, p.125-137, 2003. http://webcache.googleusercontent.com/ search?q=cache:KOhZaWxDCawJ:https://sigaa.ufrn.br/sigaa/verProducao\% 3FidProducao\%3D885331\%26key\%3D2a9ba33f1090f3e9f1 f80d703decf45 $\mathrm{e}+\& \mathrm{~cd}=1 \& \mathrm{hl}=\mathrm{pt}-\mathrm{BR} \& \mathrm{ct}=\mathrm{clnk} \& \mathrm{gl}=\mathrm{br}$

BARROSO, G.M.; PEIXOTO, A.L.; ICHASO, C.L.F.;GUIMARÃES, E.F.; COSTA, C.G. Sistemática de angiospermas do Brasil. 2. ed. Viçosa: Editora UFV, 2007. 309 p.

BARROSO, G.M; MORIN, M.P.; PEIXOTO, A.L.; ICHASO, C.L.F. Frutos e sementes: morfologia aplicada à sistemática de dicotiledôneas. Viçosa: Editora UFV, 2004. 443 p.

BASKIN, C.C., BASKIN, J.M. Seeds: ecology, biogeography and evolution of dormancy and germination, 2ed. San Diego, CA, USA: Academic/Elsevier, 2014. 205p.

BENINCASA, M.M.P. Análise de crescimento de plantas: noções básicas. Jaboticabal: FUNEP, 2003. 41 p.

CARNEIRO, M.A.C.; SIQUEIRA, J.O.; MOREIRA, F.M.S.; CARVALHO, D.; BOTELHO, S.A.; JUNIOR, O.J.S. Micorrizaarbuscular em espécies arbóreas e arbustivas de ocorrência no sudeste do Brasil. Cerne, v.4, n.1, p.129-145, 1998. http://www.dcf.ufla.br/cerne/artigos/13-02-20093894v4_ n1_artigo\%2009.pdf

CARVALHO, N.M.; NAKAGAWA, J. Sementes: ciência, tecnologia e produção. 5 ed. Jaboticabal: FUNEP, 2012. 588 p.

CHEVREUIL, L.R.; GONÇALVES, J.F.C.; SCHIMPL, F.C.; SOUZA, C.S.C.R.; SOUZA, L.A.G.; PANDO, S.C. Prospecção de inibidores de serinoproteinases em folhas de leguminosas arbóreas da floresta Amazônica. Acta Amazonica, v.41, n.1, p.163-170, 2011. http://www.scielo.br/pdf/aa/ v41n1/a19v41n1.pdf

CORNER, E. J. H. The leguminous seed. Phytomorphology, v.1, p.117-150. 1951.

DAMIÃO-FILHO, C.F.; MÔRO, F.V. Morfologia vegetal. 2. ed. Jaboticabal: FUNEP, 2005. $172 \mathrm{p}$.

DUCKE, W.A. Plantes nouvelles ou peu connues de la région amazonienne (IIIe partie). Archivos do Jardim Botânico do Rio de Janeiro, v.4, p.62-63, 1925. http://www.biodiversitylibrary.org/page/31246559\#page/484/mode/1up

ESAU, K. Anatomia das plantas com sementes. São Paulo: Edgard Blucher, 1993. $293 \mathrm{p}$.

FERREIRA, L.V.; VENTICINQUE, E.; ALMEIDA, S.S. O desmatamento na Amazônia e a importância das áreas protegidas. Estudos Avançados, v.19, n.53, p.1-10, 2005. http://www.scielo.br/pdf/ea/v19n53/24086.pdf

JOHANSEN, D.L. Plant microtechnique. New York: McGraw-Hill, 1940. 222 p.

KRAUS, J.E., SOUSA, H.C., REZENDE, M.H., CASTRO, N.M., VECCHI,
C.; LUQUE, R. Astra blue and basic fucsin double staining of plant materials. Biotechnie \& Histochemistry, v.73, p.235-243, 1998.http://informahealthcare. com/doi/abs/10.3109/10520299809141117?journalCode=bih

LARCHER, W. Ecofisiologia vegetal. São Carlos: RIMAArtes e Textos, 2006. $532 \mathrm{p}$.

LEWIS, N.G.; YAMAMOTO, E. Lignin: occurrence, biogenesis and biodegradation. Annual Review of Plant Physiology Plant Molecular Biology, v.41, p.455-496, 1990. http://www.annualreviews.org/doi/pdf/10.1146/ annurev.pp.41.060190.002323

LORENZI, H. Árvores brasileiras: manual de identificação e cultivo de plantas arbóreas nativas do Brasil. Nova Odessa: Instituto Plantarum, v.2, $2002.368 \mathrm{p}$.

MELO-PINNA, G.F.; NEIVA, M.S.M.; BARBOSA, D.C.A. Estrutura do tegumento seminal de quatro espécies de Leguminosae (Caesalpinioideae), ocorrentes numa área de caatinga ( $\mathrm{PE}$ - Brasil). Revista Brasileira de Botânica, v.22, n.3, p.375-379, 1999.http://www.scielo.br/pdf/rbb/v22n3/22(3)a04.pdf

PEZZATO-DA-GLÓRIA, B.; CARMELLO-GUERREIRO, S.M. (Editoras) Anatomia Vegetal. $2^{\mathrm{a}}$ ed. Viçosa: Ed. UFV, 2006. 438 p.

RAVEN, P.H.; EVERT, R.F.; EICHHORN, S.E. Biologia Vegetal. São Paulo: Editora Guanabara Koogan S. A., 2007. 856 p.

REGO, S.S.; SILVA, A.J.C.; BRONDANI, G.E.; GRISI, F.A.; NOGUEIRA, A.C.; KUNIYOSHI, Y.S. Caracterização morfológica do fruto, semente e germinação de Duranta vestita Cham. (Verbenaceae). Revista Brasileira de Biociencias, v.5, p. 474-476, 2007. http://www.ufrgs.br/seerbio/ojs/index. $\mathrm{php} / \mathrm{rbb} /$ article/viewFile/480/383

RODRIGUES, T.M.; MACHADO, S.R.Anatomia comparada do pulvino primário de leguminosas com diferentes velocidades de movimento foliar. Revista Brasileira de Botânica, v.29, n.4, p. 709-720, 2006. http://www. scielo.br/pdf/rbb/v29n4/19.pdf

RODRIGUES, R.S.; TOZZI, A.M.G.A. Morfologia de plântulas de cinco leguminosas genistóides arbóreas do Brasil (Leguminosae-Papilionoideae) Acta Botanica Brasilica, v.21, n.3, p.599-607, 2007. http://www.scielo.br/ $\mathrm{pdf} / \mathrm{abb} / \mathrm{v} 21 \mathrm{n} 3 / \mathrm{a} 07 \mathrm{v} 21 \mathrm{n} 3 . \mathrm{pdf}$

SANTOS, J.M. Microscopia de varredura aplicada às ciências biológicas. Jaboticabal: FUNEP, 1996. 56 p.

SASS, J.E. Elements of botanical microtechnique. New York: McGraw-Hill Book Company, 1958. $222 \mathrm{p}$

SILVA, B.M.S.; MÔRO, F.V. Aspectos morfológicos do fruto, da semente e desenvolvimento pós-seminal de faveira (Clitoria fairchildiana R. A Howard. - Fabaceae). Revista Brasileira de Sementes, v.30, n.3, p.195-201, 2008. http://www.scielo.br/pdf/rbs/v30n3/26.pdf

SOUZA, V.C.; LORENZI, H. Botânica sistemática: guia ilustrado para identificação das famílias de angiospermas da flora brasileira, baseado em APGIII. Ed. 3. Nova Odessa: Instituto Plantarum de Estudos da Flora Ltda. 2012. $640 \mathrm{p}$ 